\title{
Front Matter: Volume 10095
}

"Front Matter: Volume 10095," Proc. SPIE 10095, Laser 3D Manufacturing IV, 1009501 (27 April 2017); doi: 10.1117/12.2276270

SPIE. Event: SPIE LASE, 2017, San Francisco, California, United States 


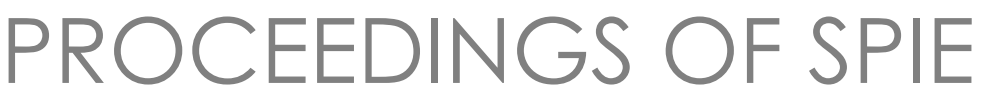

\title{
Laser 3D Manufacturing IV
}

\author{
Bo Gu \\ Henry Helvajian \\ Alberto Piqué \\ Corey M. Dunsky \\ Jian Liu \\ Editors
}

30 January-2 February 2017

San Francisco, California, United States

Sponsored by

SPIE

Cosponsored by

PolarOnyx, Inc. (United States)

Published by

SPIE 
The papers in this volume were part of the technical conference cited on the cover and title page. Papers were selected and subject to review by the editors and conference program committee. Some conference presentations may not be available for publication. Additional papers and presentation recordings may be available online in the SPIE Digital Library at SPIEDigitallibrary.org.

The papers reflect the work and thoughts of the authors and are published herein as submitted. The publisher is not responsible for the validity of the information or for any outcomes resulting from reliance thereon.

Please use the following format to cite material from these proceedings:

Author(s), "Title of Paper," in Laser 3D Manufacturing IV, edited by Bo Gu, Henry Helvajian, Alberto Piqué, Corey M. Dunsky, Jian Liu, Proceedings of SPIE Vol. 10095 (SPIE, Bellingham, WA, 2017) Seven-digit Article CID Number.

ISSN: 0277-786X

ISSN: 1996-756X (electronic)

ISBN: 9781510606319

ISBN: 9781510606326 (electronic)

Published by

SPIE

P.O. Box 10, Bellingham, Washington 98227-0010 USA

Telephone +1 3606763290 (Pacific Time) · Fax +1 3606471445

SPIE.org

Copyright @ 2017, Society of Photo-Optical Instrumentation Engineers.

Copying of material in this book for internal or personal use, or for the internal or personal use of specific clients, beyond the fair use provisions granted by the U.S. Copyright Law is authorized by SPIE subject to payment of copying fees. The Transactional Reporting Service base fee for this volume is $\$ 18.00$ per article (or portion thereof), which should be paid directly to the Copyright Clearance Center (CCC), 222 Rosewood Drive, Danvers, MA 01923. Payment may also be made electronically through CCC Online at copyright.com. Other copying for republication, resale, advertising or promotion, or any form of systematic or multiple reproduction of any material in this book is prohibited except with permission in writing from the publisher. The CCC fee code is 0277-786X/17/\$18.00.

Printed in the United States of America.

Publication of record for individual papers is online in the SPIE Digital Library.

\section{SPIE. DIGITAL}

Paper Numbering: Proceedings of SPIE follow an e-First publication model. A unique citation identifier (CID) number is assigned to each article at the time of publication. Utilization of CIDs allows articles to be fully citable as soon as they are published online, and connects the same identifier to all online and print versions of the publication. SPIE uses a seven-digit CID article numbering system structured as follows:

- The first five digits correspond to the SPIE volume number.

- The last two digits indicate publication order within the volume using a Base 36 numbering system employing both numerals and letters. These two-number sets start with 00, 01, 02, 03, 04, 05, $06,07,08,09,0 A, 0 B \ldots$.. OZ, followed by 10-1Z, 20-2Z, etc. The CID Number appears on each page of the manuscript. 


\title{
Contents
}

\author{
$\checkmark \quad$ Authors \\ vii Conference Committee \\ ix Introduction
}

\section{LASER DIRECT WRITING AND LIFT}

1009506 Modeling of selective laser sintering/selective laser melting [10095-4]

1009507 How post-processing by selective thermal reflow can reduce the roughness of 3D lithography in micro-optical lenses (Invited Paper) [10095-5]

\section{ADDITIVE PROCESSES WITH ULTRAFAST LASER AND OF GLASS}

10095 OC Microfluidic diffusivity meter: a tool to optimize $\mathrm{CO}_{2}$ driven enhanced oil recovery [10095-31]

PROCESS AND POST PROCESS DEVELOPMENT AND MATERIALS FOR ADDITIVE MANUFACTURING II

10095 OG Laser additive manufacturing of multimaterial tool inserts: a simulation-based optimization study [10095-13]

10095 Ol Brillovin micro-elastography of laser processed materials [10095-15]

10095 0J 3D scanning and printing of airfoils for modular UAS [10095-16]

\section{LASER 3D MICRO/NANO STRUCTURING II}

10095 OQ Bulk diamond optical waveguides fabricated by focused femtosecond laser pulses (Invited Paper) [10095-23]

INDUSTRIAL APPLICATIONS AND SYSTEMS FOR ADDITIVE MANUFACTURING I

10095 OU Wire-based laser metal deposition for additive manufacturing of TiAl6V4: basic investigations of microstructure and mechanical properties from build up parts [10095-27] 
10095 0X Development of 100W class blue direct diode laser coating system for laser metal deposition [10095-32]

$100950 Z$ Effect on beam profile of Ti alloy plate fabrication from powder by sputter-less selective laser melting [10095-34]

1009511 Multifunctional cube-like system for biomedical applications featuring 3D printing by dual deposition, scanner, and UV engraving [10095-36]

1009512 Galvanometer scanning technology for laser additive manufacturing [10095-37]

1009514 Coordinate measuring system based on microchip lasers for reverse prototyping [10095-40] 


\section{Authors}

Numbers in the index correspond to the last two digits of the six-digit citation identifier (CID) article numbering system used in Proceedings of SPIE. The first four digits reflect the volume number. Base 36 numbering is employed for the last two digits and indicates the order of articles within the volume. Numbers start with 00, 01, 02, 03, 04, 05, 06, 07, 08, 09, 0A, 0B...0Z, followed by 10-1Z, 20-2Z, etc.

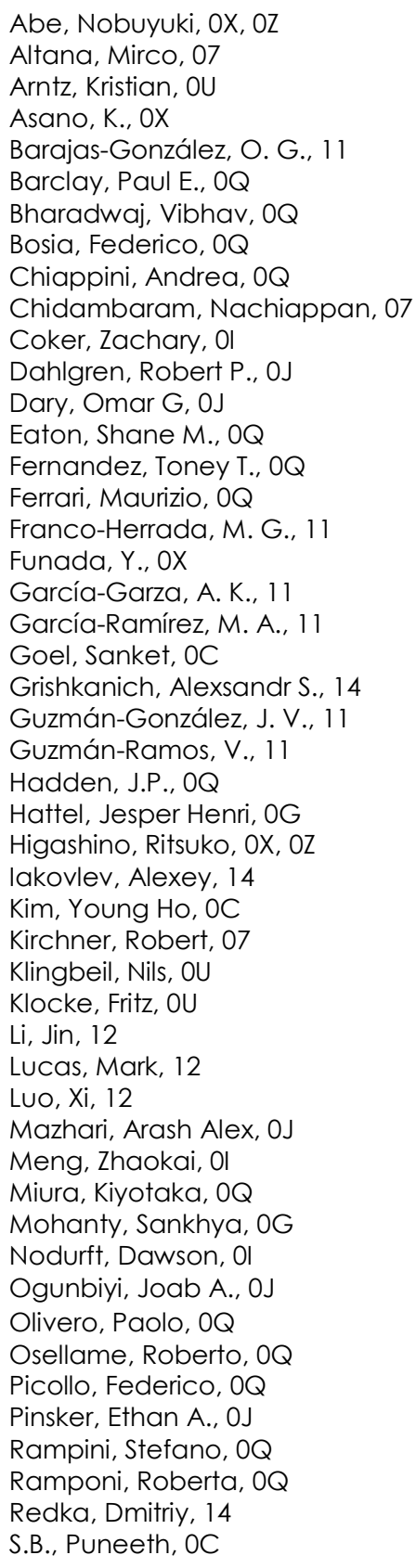


Proc. of SPIE Vol. 10095 1009501-6

Downloaded From: https://www.spiedigitallibrary.org/conference-proceedings-of-spie on 26 Apr 2023 Terms of Use: https://www.spiedigitallibrary.org/terms-of-use 


\title{
Conference Committee
}

\author{
Symposium Chairs
}

Reinhart Poprawe, Fraunhofer-Institut für Lasertechnik (Germany)

Koji Sugioka, RIKEN (Japan)

Symposium Co-chairs

Guido Hennig, Daetwyler Graphics AG (Switzerland)

Yongfeng Lu, University of Nebraska-Lincoln (United States)

Program Track Chairs

Beat Neuenschwander, Berner Fachhochschule Technik und Informatik (Switzerland)

Henry Helvajin, The Aerospace Corporation (United States)

Conference Chairs

Bo Gu, Bos Photonics (United States)

Henry Helvajian, The Aerospace Corporation (United States)

Alberto Piqué, U.S. Naval Research Laboratory (United States)

Corey M. Dunsky, Aeos Consulting, Inc. (United States)

Jian Liu, PolarOnyx, Inc. (United States)

Conference Program Committee

John T. Fourkas, University of Maryland, College Park (United States)

Youping Gao, Aerojet Rocketdyne (United States)

Craig Goldberg, Newport Corporation (United States)

Weidong Huang, Northwestern Polytechnical University (China)

Michael Thiel, Nanoscribe GmbH (Germany)

Paul S. Unwin, Stanmore Implants (United Kingdom)

Augustine M. Urbas, Air Force Research Laboratory (United States)

Martin Wegener, Karlsruher Institut für Technologie (Germany)

Conference Review Committee

Georg von Freymann, Technische Universität Kaiserslautern

(Germany)

Session Chairs

1 Laser Direct Writing and LIFT

Alberto Piqué, U.S. Naval Research Laboratory (United States) 
2 Additive Processes with Ultrafast Laser and of Glass

Jian Liu, PolarOnyx, Inc. (United States)

3 Direct Laser Writing for Biological and Medical Applications: Joint Session with Conferences 10115 and 10095

Michael Thiel, Nanoscribe GmbH (Germany)

4 3D Laser Lithography for Production: Joint Session with Conferences 10115 and 10095

Mangirdas Malinauskas, Vilnius University (Lithuania)

5 3D Laser Lithography: Joint Session with Conferences 10115 and 10095

Yuebing Zheng, The University of Texas at Austin (United States)

Nico Tucher, Fraunhofer-Institut für Solare Energiesysteme (Germany)

6 Process and Post Process Development and Materials for Additive Manufacturing I

Henry Helvajian, The Aerospace Corporation (United States)

7 Process and Post Process Development and Materials for Additive Manufacturing II

Alberto Piqué, U.S. Naval Research Laboratory (United States)

8 Laser 3D Micro/Nano Structuring I

Corey M. Dunsky, Aeos Consulting, Inc. (United States)

9 Laser 3D Micro/Nano Structuring II

Henry Helvajian, The Aerospace Corporation (United States)

10 Industrial Applications and Systems for Additive Manufacturing I

Jian Liu, PolarOnyx, Inc. (United States) 


\section{Introduction}

Laser Additive Manufacturing(LAM), or 3D Laser Printing, has opened up new opportunities while facing up to many challenges. Market analysts valued the global 3D printing market at $\$ 2.3 \mathrm{~B}$ in 2013 and are projecting global revenues of $\$ 8.6 \mathrm{~B}$ by 2020 -an impressive compound annual growth rate of more than $20 \%$ over seven years! At the same time, it is estimated that 3D printing will become $50 \%$ less expensive and $400 \%$ faster over the next five years. However, 3D printing technology can only reach its economic potential and fulfill its promise of revolutionizing manufacturing across multiple industries if a number of significant real-world structural challenges are addressed. The Laser 3D Printing Manufacturing Conference at Photonics West provides such a forum to discuss and address some of these challenges. It has become the conference where professionals from multiple disciplines share and discuss the latest advances in the field of laser-based digital manufacturing and the development and implementation of next generation laser-based 3D manufacturing processes. We believe that this type of cross talk and communication amongst conference speakers and attendees from all fields related to LAM, which include material science, laser processing physics/chemistry, mechanical engineering, software and designing tools, modeling, characterization and metrology, is not only necessary for maturing the field but very much needed to spark new ideas.

Potentially a disruptive game changer, 3D Laser Printing is still a relatively new technology and definitely needs further development. While it has already been disrupting the manufacturing value chain and allowing a path to mass producing customized products, and in some applications it has already reached a tipping point of maturity. However, many issues remain that need to be tackled. We will continue to encourage researchers and engineers to submit their work to this conference to help fully reach LAM potential.

Finally, we would like to thank all of the speakers and attendees for their great contribution to the conference. We hope that more people will come and share their work and exchange ideas at this unique platform next year. After all, this is what this conference is all about--it is for you.

Bo Gu

Henry Helvajian

Alberto Piqué

Corey M. Dunsky

Jian Lu 
Proc. of SPIE Vol. 10095 1009501-10

Downloaded From: https://www.spiedigitallibrary.org/conference-proceedings-of-spie on 26 Apr 2023 Terms of Use: https://www.spiedigitallibrary.org/terms-of-use 